\title{
Effect of dietary fish oil supplements alone or in combination with sunflower and linseed oil on ruminal lipid metabolism and bacterial populations in lactating cows
}

\author{
P. Kairenius,${ }^{* 1}$ H. Leskinen, ${ }^{*}$ V. Toivonen, ${ }^{*}$ S. Muetzel,† S. Ahvenjärvi, ${ }^{*}$ A. Vanhatalo,‡ P. Huhtanen, ${ }^{*} \S$ \\ R. J. Wallace,\# and K. J. Shingfield ${ }^{* 2}$ \\ *Milk Production Solutions, Green Technology, Natural Resources Institute Finland (Luke), Jokioinen, FI-31600, Finland \\ †AgResearch Ltd., Grasslands Research Centre, Private Bag 11-008, Palmerston North 4442, New Zealand \\ ‡Department of Agricultural Sciences, University of Helsinki, PO Box 28, FI 00014, Finland \\ §Department of Agriculture in Northern Sweden, Swedish University of Agricultural Sciences, S-90183, Umeå, Sweden \\ \#Rowett Institute of Nutrition and Health, University of Aberdeen, Bucksburn, Aberdeen, AB21 9SB, United Kingdom
}

\begin{abstract}
Fish oil (FO) alters ruminal biohydrogenation causing trans fatty acid (FA) intermediates to accumulate, but the effects of 18-carbon polyunsaturated FA supply on ruminal long-chain FA metabolism and microbial communities in cattle fed FO are not well established. Four cows fitted with rumen cannula were used in a $4 \times 4$ Latin square with 21-d experimental periods to evaluate the effects of $\mathrm{FO}$ alone or in combination with plant oils high in $18: 2 \mathrm{n}-6$ or $18: 3 \mathrm{n}-3$ on rumen microbial ecology and flow of FA at the omasum. Treatments comprised a basal grass silage-based diet containing no additional oil (control) or supplements of FO $(200 \mathrm{~g} / \mathrm{d})$ or FO $(200 \mathrm{~g} / \mathrm{d})$ plus $500 \mathrm{~g} / \mathrm{d}$ of sunflower oil (SFO) or linseed oil (LFO). Flow of FA was determined using the omasal sampling technique. The relative abundance of key biohydrogenating bacteria was assessed by quantitative PCR on $16 \mathrm{~S}$ rRNA genes in omasal digesta. Fish oil-supplemented treatments increased the amounts of trans-18:1, trans-18:2, and 20to 22-carbon polyunsaturated FA escaping the rumen. Relative to the control, oil supplements had no effect on the amount of 18:0 leaving the rumen, but LFO decreased the flow of 18:0 at the omasum compared with SFO. Both SFO and LFO increased trans-18:1 relative to $\mathrm{FO}$, whereas $\mathrm{LFO}$ resulted in the highest trans-18:2 and 20- to 22-carbon FA flow. Supplements of FO plus plant oils shifted biohydrogenation toward trans-10 18:1 formation. Compared with FO alone, the ruminal metabolism of 22:6n-3 in the rumen of lactating cows is more extensive on diets containing higher
\end{abstract}

\footnotetext{
Received September 1, 2017.

Accepted December 14, 2017.

${ }^{1}$ Corresponding author: piia.kairenius@luke.fi

${ }^{2}$ Deceased.
}

amounts of 18-carbon polyunsaturated FA. However, the biohydrogenation of 22:5n-3 was less extensive in LFO than SFO, but showed no difference between FO and diets containing plant oils. Ruminal outflow of 20:5n-3 was not altered when plant oils were added to FO. Alterations in the amount of intermediates at the omasum or ruminal biohydrogenation pathways were not accompanied by major changes in analyzed bacterial populations. In conclusion, dietary supplements of FO alone or in combination with plant oils increase the amount of biohydrogenation intermediates containing 1 or more trans double bonds escaping the rumen, which may have implications for host metabolism and the nutritional quality of ruminant foods.

Key words: polyunsaturated fatty acid, plant oil, biohydrogenation, Butyrivibrio

\section{INTRODUCTION}

Due to the potential benefits for human health, there is interest in increasing cis-9,trans-11 CLA and longchain n-3 fatty acids (FA) and lowering the concentration of medium-chain FA in ruminant milk (Lock and Bauman, 2004; Palmquist et al., 2005; Shingfield et al., 2013). Most of the cis-9,trans-11 CLA in milk originates from the desaturation of trans-11 18:1 in the mammary gland (Griinari et al., 2000). Trans-11 18:1 is the penultimate intermediate formed during the biohydrogenation of 18-carbon PUFA to 18:0 in the rumen (Harfoot and Hazlewood, 1988). Dietary supplements of plant oils high in 18:2n-6 (Shingfield et al., 2008a) and 18:3n-3 (Loor et al., 2004) or fish oil (FO; Shingfield et al., 2003) are known to increase trans-11 18:1 formation in the rumen in lactating cows. Feeding diets containing FO and sources of $18: 2 \mathrm{n}-6$ or $18: 3 \mathrm{n}$ 3 increase cis-9,trans-11 CLA concentrations in milk from lactating cows (Whitlock et al., 2002; Palmquist and Griinari, 2006), but enrichment varies depending 
on the composition of the basal diet and the amount and source of lipid supplement. Furthermore, dietary supplements of oils containing $18: 2 \mathrm{n}-6$ or $18: 3 \mathrm{n}-3$, but not FO, lower the proportions of 12:0, 14:0, and 16:0 in milk fat (Shingfield et al., 2013).

In vitro studies have demonstrated that $18: 2 \mathrm{n}-6$ and 18:3n-3 decrease the biohydrogenation of $20: 5 n-3$ and 22:6n-3 and cause trans-11 18:1 to accumulate (Chow et al., 2004; Wasowska et al., 2006). In growing cattle, dietary supplements of a mixture (1:1 wt/wt) of FO and linseed oil (LO) lowered ruminal biohydrogenation of 20:5n-3 and 22:6n-3 and increased trans-11 18:1 at the duodenum compared with the same amount of oil from FO alone (Shingfield et al., 2011). These findings suggest that dietary supplements of a mixture of plant oils and FO could be used to increase ruminal escape of trans-11 18:1, 18-carbon PUFA, and long-chain n-3 FA for incorporation into meat and milk.

Changes in ruminal biohydrogenation to dietary FO supplements are accompanied by alterations in the ruminal bacterial community capable of biohydrogenation (Kim et al., 2008; Huws et al., 2010; Shingfield et al., 2012). Populations of specific bacteria in the rumen were found to be altered by marine algae supplements in sheep fed diets containing sunflower oil (SO; Toral et al., 2012), but no reports exist on the effects of FO with plant oils on the abundance of biohydrogenating bacteria in cattle. Characterizing the effects on ruminal biohydrogenation is central to understanding the mechanisms underpinning physiological responses to lipid supplements in lactating ruminants and the effect on milk fat composition, which is a major source of SFA in the human diet (Eilander et al., 2015).

The present experiment tested the hypotheses that (1) plant-derived 18-carbon PUFA may lower ruminal biohydrogenation of long-chain n-3 FA in FO and increase trans-11 18:1, (2) that the resultant accumulation of intermediates is associated with changes in the key bacterial species known to be capable of biohydrogenation, and (3) that the effects may differ depending on whether $18: 2 \mathrm{n}-6$ or $18: 3 \mathrm{n}-3$ is the main source of PUFA. The experimental treatments were formulated to meet the objectives of providing new information on changes in ruminal biohydrogenation of long-chain polyenoic FA, metabolic pathways involved, and specific FA products and intermediates associated with these diets.

\section{MATERIALS AND METHODS}

\section{Cows and Experimental Design}

All experimental procedures were approved by the Animal Experiment Committee of MTT Agrifood
Research Finland in accordance with the guidelines established by the European Community Council Directive 86/609/EEC (European Council, 1986). Four multiparous Finnish Ayrshire cows (193 \pm 16.2 d postpartum, $637 \pm 22.3 \mathrm{~kg}$ of live weight, and producing $24.8 \pm 4.73 \mathrm{~kg}$ of milk/d) fitted with rumen cannulas (i.d. 100 mm; Bar Diamond Inc., Parma, ID) were used in a $4 \times 4$ Latin square with 21 -d experimental periods. Treatments comprised a basal diet containing no additional oil (control), or supplemented with $200 \mathrm{~g}$ of ultra refined herring and mackerel oil (EPAX 3000 TG Pronova Biocare AS, Aalesund, Norway; treatment FO), $200 \mathrm{~g}$ of FO and $500 \mathrm{~g}$ of SO (Raisioagro Ltd., Raisio, Finland; SFO) or $200 \mathrm{~g}$ of FO and $500 \mathrm{~g}$ of LO per day (Elixi Oil Ltd., Somero, Finland; LFO; Supplemental Table S1; https://doi.org/10.3168/jds .2017-13776). Cows were housed in individual tiestalls within a dedicated metabolism unit with continuous access to water and salt block and were milked daily at 0700 and 1645.

\section{Experimental Diets}

Cows were offered grass silage and a cereal-based concentrate (forage:concentrate ratio 60:40, on a DM basis) as equal meals at 0600 and 1800 at $95 \%$ of ad libitum intake measured during 14-d before the start of the experiment. Experimental silage was prepared from primary growths of mixed timothy (Phleum pratense) and meadow fescue (Festuca pratensis). The concentrate supplement contained $(\mathrm{g} / \mathrm{kg})$ : rolled barley $(520)$, molassed sugar beet pulp (250), solvent extracted rapeseed meal (200) of low glucosinolate content (Raisioagro Ltd., Raisio, Finland), and a mineral and vitamin premix (30; Onni-Kivennäinen, Rehumelica, Vaasa, Finland). Oil supplements were fed in equal amounts at 0600 and 1800 by mixing with concentrate ingredients immediately before feeding.

\section{Sampling and Chemical Analysis}

Intake of each cow was measured daily. Representative samples of feed ingredients and feed refusals were collected daily over the last $5 \mathrm{~d}$ of each experimental period for analysis of chemical composition (Shingfield et al., 2002). Samples of ruminal fluid $(\mathrm{n}=8)$ were collected from each cow at 1.5-h intervals from 0600 to $1500 \mathrm{~h}$ on d 20 (0600, 0730, 0900, 1030, 1200, 1330, and $1500 \mathrm{~h}$, respectively). Samples (approximately $500 \mathrm{~mL}$ ) were collected through rumen cannula using a vacuum pump and flexible tube and analyzed for $\mathrm{pH}$, VFA and ammonia N concentrations (Shingfield et al., 2002). An additional $10-\mathrm{mL}$ subsample of filtered rumen fluid was diluted with $30 \mathrm{~mL}$ of $0.9 \%$ (wt/vol) aqueous $\mathrm{NaCl}$ 
containing $10 \%$ ( vol/vol) of formaldehyde for visual assessment $(\mathrm{n}=6)$ of protozoal numbers using a counting chamber (Fuchs-Rosenthal, Fortuna, Germany).

The flow of digesta at the omasal canal was determined using the omasal sampling technique (Ahvenjärvi et al., 2000) and a triple indigestible marker system based on Cr-EDTA, Yb-acetate (Dasico A/S, Birkerød, Denmark), and indigestible NDF as markers for liquid, small, and large particles, respectively (Shingfield et al., 2008b). The Cr-EDTA was prepared according to standard procedures (Binnerts et al., 1968); Cr-EDTA $(978 \mathrm{~g})$ and $\mathrm{Yb}$-acetate $(5.8 \mathrm{~g})$ were dissolved in distilled water $(6 \mathrm{~kg})$ and infused separately into the rumen at a constant rate $(4.2 \mathrm{~mL} / \mathrm{min})$ using a peristaltic pump (Watson-Marlow, High Wycombe, UK) starting at 1800 $\mathrm{h}$ on d 14 of each period. To facilitate rapid equilibration of marker concentrations in the rumen, cows also received priming doses of Cr-EDTA $(1,500 \mathrm{~g})$ and $\mathrm{Yb}$ acetate $(7.5 \mathrm{~g})$ at the start of marker administration.

Spot samples $(500 \mathrm{~mL})$ of digesta entering the omasal canal were collected 3 times daily at 4-h intervals from d 17 to 20 , to cover a 12-h period that was considered representative of the entire feeding cycle composited, and separated into large particle, small particle, and liquid phases (Ahvenjärvi et al., 2000). Each phase was freeze-dried and stored at $-20^{\circ} \mathrm{C}$, whereas subsamples of each fraction collected for FA and bacterial community analysis were stored at $-80^{\circ} \mathrm{C}$.

Marker concentrations and chemical composition of omasal digesta were determined using standard methods (Ahvenjärvi et al., 2000). Digesta flows entering the omasal canal were calculated after mathematical reconstitution for a triple marker method (Ahvenjärvi et al., 2000). Administration of markers was based on the excretion in feces. Thereafter, appropriate amounts of freeze-dried digesta previously stored at $-80^{\circ} \mathrm{C}$ were weighted to yield two 10-g composite samples, one for FA analysis and the other for measurements of bacterial populations.

Whole-tract apparent digestibility coefficients were determined by total fecal collection over $120 \mathrm{~h}$ starting at $1800 \mathrm{~h}$ on d 17 of each experimental period. Urine was separated from feces by means of a light harness and flexible tubing attached to the vulva. Total feces excreted was weighed, thoroughly mixed, subsampled $(5 \%$, wt $/ \mathrm{vol})$, and stored at $-20^{\circ} \mathrm{C}$ until analyzed for chemical composition using the same methods applied to feeds and marker concentrations using the same procedures applied to omasal digesta.

\section{DNA Extraction from Omasal Digesta}

Samples of freeze-dried, reconstituted omasal digesta $(0.2 \mathrm{~mL})$ were collected into lysis tubes from the Qbio- gene FastDNA SPIN Kit (Qbiogene, Carsbad, CA) for Soil before DNA extraction (Shingfield et al., 2012; Halmemies-Beauchet-Filleau et al., 2013). The integrity of the DNA was checked on 1\% (wt/vol) agarose gels and the purity was assessed from the $260 / 280 \mathrm{~nm}$ ratio; purity of DNA was considered acceptable with ratios $>1.8$.

\section{Quantitative PCR of the Bacteria}

For quantitative PCR reactions, the DNA was diluted 10 fold, except for the determination of total bacteria, when 100-fold dilutions were used. Quantitative PCR was performed using Sigma JumpStart PCR mixes with or without Sybr Green (Sigma-Aldrich, St. Louis, MO), as outlined earlier (Shingfield et al., 2012; Halmemies-Beauchet-Filleau et al., 2013). Primer sets and probes used in quantitative PCR are presented in Supplemental Table S2 (https://doi.org/10.3168/jds .2017-13776). The specificity of the primers and probes was validated on the same set of strains used in earlier reports (Paillard et al., 2007; Shingfield et al., 2012; Halmemies-Beauchet-Filleau et al., 2013). Calibration was carried out using DNA from a mixture of known target organisms. Responses were also tested using the same DNA added to DNA extracted from omasal digesta (Shingfield et al., 2012; Halmemies-Beauchet-Filleau et al., 2013). The specificity of different primer sets, 2 in combination with probes, to members of the Butyrivibrio/Pseudobutyrivibrio group is described in earlier reports (Shingfield et al., 2012; Halmemies-BeauchetFilleau et al., 2013) and shown in Supplemental Figure S1 (https://doi.org/10.3168/jds.2017-13776).

\section{FA Analysis}

Fatty acid methyl esters of lipids in oil supplements and freeze-dried feed samples were prepared using standard methods (Shingfield et al., 2003). Lipids in $200 \mathrm{mg}$ of freeze-dried samples of reconstituted omasal digesta were extracted in duplicate (Shingfield et al., 2003), organic extracts were combined and dried under oxygen-free $\mathrm{N}$ at $50^{\circ} \mathrm{C}$, and lipids were converted to FAME (Kairenius et al., 2011). Fatty acid content was determined using the internal and external standards. Tritridecanoin (0.1 wt/vol in hexane; T-135, Nu-Chek Prep Inc., Elysian, MN) and tridecanoic acid (0.1 wt/ vol in absolute ethanol; N13-A, Nu-Chek Prep) were used as an internal standards for feed ingredients and omasal digesta, respectively. Trihexadecanoin (T-5888, Sigma-Aldrich) and hexadecanoic acid (S-4751, SigmaAldrich) were used to set up an external calibration curve for feed ingredients and omasal digesta, respectively. 
Fatty acid methyl esters were quantified using a GC (6890; Agilent Technologies, Wilmington, DE) fitted with a 100-m fused silica capillary column (CP-Sil 88; Chrompack 7489, Chrompack International BV, Middelburg, the Netherlands) using a temperature gradient program and hydrogen as the carrier gas (Shingfield et al., 2003). Individual isomers of 18:1 and 18:2 were further resolved in a separate analysis under isothermal conditions at $170^{\circ} \mathrm{C}$ (Shingfield et al., 2003). Under these conditions, trans-10,cis-15 18:2 and trans-11,cis-15 18:2 eluted as a single peak. To resolve these isomers, analysis of FAME was repeated using a SLB-IL111 column $(100 \mathrm{~m} \times 0.25 \mathrm{~mm}$ i.d., $0.2 \mu \mathrm{m}$ film thickness, SigmaAldrich) and helium as a carrier gas (Ventto et al., 2017). Peaks were initially identified based on retention time comparisons with authentic FAME standards (Nu-Chek Prep GLC \#463; 21:0, \#N-21-M; 23:0, \#N23-M; 24:0, \#N-24-M; trans-11 20:1, \#U-64-M; cis-1221:1, \#U-85-M; cis-14 23:1, \#U-87-M, Larodan Fine Chemicals 18:4n-3, \#10-1840; cis-9 20:1, \#20-2001-1-4; 20:4n-3, \#20-2024-1; 21:3n-3, \#20-2103-1-4; 21:5n-3, \#20-2105-1-4; trans-13 22:1, \#20-2210-9; 22:5n-6, \#202265-7; 23:5n-3, \#20-2305-1-4; 24:5n-3, \#20-2405-4; 25:0, \#20-2500-7; 29:0, \#20-2900-7; 9-O-18:0, \#141800-5-4; 12-O-18:0, \#14-1800-6-4; 13-O-18:0, \#141800-7-4; 16-O-18:0, \#14-1800-8-39 (Malmo, Sweden), and Sigma-Aldrich 26:0, \#H-6389; 27:0, \#H-6639; 28:0, \#O-4129; 30:0 \#T-1902; mixture of 18:2n-6 isomers, \#L-8404; mixture of conjugated 18:2 isomers, \#O5632; mixture of 18:3n-3 isomers, \#L-6031). Fatty acid methyl esters not available as commercial standards were identified in omasal digesta based on complementary silver-ion $\left(\mathrm{Ag}^{+}\right)$thin-layer chromatography and GC-MS analysis of FAME and 4,4-dimethyloxazoline derivatives prepared for each recovered FAME band (Kairenius et al., 2011; Halmemies-Beauchet-Filleau et al., 2013). The distribution of CLA isomers in omasal digesta was determined by $\mathrm{Ag}^{+}$-HPLC (Shingfield et al., 2003). Analysis was repeated using $2.0 \%$ (vol/ $\mathrm{vol}$ ) acetic acid in heptane to resolve cis-10,trans-12 CLA and trans-10,cis-12 CLA (Ventto et al., 2017).

\section{Statistical Analysis}

Dry matter intake recorded during the last $5 \mathrm{~d}$ of each experimental period were averaged before statistical analysis. Experimental data were analyzed by ANOVA for a $4 \times 4$ Latin square design with a model that included the random effects of cow and the fixed effects of period and experimental treatment using the mixed procedure of SAS (version 9.2, SAS Institute Inc., Cary, NC). Measurements of rumen $\mathrm{pH}$ and fermentation characteristics were analyzed by ANOVA for repeated measures with a model that included the fixed effect of period, treatment, time, and treatment $x$ time interactions and the random effect of cow using an autoregressive order one covariance structure. Denominator degrees of freedom were calculated using the Kenward-Roger method. Sums of squares were further separated into single degree of freedom orthogonal contrasts to test the effects due to FO (control vs. FO, $\mathrm{SFO}$, and LFO), addition of plant oils in the diet (FO vs. SFO and LFO), and source of plant oil (SFO vs. LFO). Least squares means \pm standard error of the means are reported and treatment effects were considered significant at $P \leq 0.05$. Treatment effects at $P>$ 0.05 to 0.10 were considered close to significant.

\section{RESULTS}

\section{Chemical Composition of Experimental Feeds}

Experimental silage was of high quality, both in terms of nutritive value and fermentation characteristics (Supplemental Table S1; https://doi.org/10.3168/ jds.2017-13776). Lipid in grass silage contained relatively high proportions of $16: 0,18: 2 \mathrm{n}-6$, and 18:3n-3, whereas 16:0, cis-9 18:1, and 18:2n-6 predominated in concentrates. Sunflower oil contained high proportions of 18:2n-6, 18:3n-3 was the major FA in LO, and FO was relatively rich in 20:5n-3, 22:5n-3, and 22:6n-3 (Supplemental Table S1).

\section{Nutrient Intake, Digestibility, and Rumen Fermentation}

Intakes of silage DM, total DM, OM, NDF, potentially digestible NDF, and $\mathrm{CP}$ were decreased $(P<$ $0.05)$ by dietary oil supplements, and lowered further $(P<0.05)$ when $\mathrm{FO}$ was fed as a mixture with $\mathrm{SO}$ or LO (Table 1). Oil supplements increased $(P<0.001)$ the intakes of $16: 2 \mathrm{n}-4,16: 3 \mathrm{n}-4,16: 4 \mathrm{n}-1,18: 4 \mathrm{n}-3,20: 3 \mathrm{n}-$ 3, 20:4n-6, 20:4n-3, 20:5n-3, 21:5n-3, 22:3n-3, 22:5n-3, and 22:6n-3. By design, the intakes of cis-9 18:1 and 18:2n-6 were substantially higher $(P<0.001)$ for SFO than LFO, and 18:3n-3 intake was greater $(P<0.001)$ for LFO compared with SFO (Table 1). Relative to the control, oil supplements had no effect on nutrient digestibility, with the exception of a close to significant $(P=0.09)$ increase in whole-tract DM digestion (Supplemental Table S3; https://doi.org/10.3168/jds .2017-13776). Inclusion of plant oils with FO had no effect on nutrient digestion compared with FO alone (Supplemental Table S3).

Experimental treatments did not affect rumen $\mathrm{pH}$, ammonia N, or total VFA concentrations, but altered molar VFA proportions (Table 2). Oil supplements lowered $(P<0.05)$ molar proportions of acetate and cap- 
Table 1. Feed and nutrient intake of lactating cows fed a grass silage-based diet supplemented with fish oil or a mixture of fish oil with either sunflower oil or linseed oil

\begin{tabular}{|c|c|c|c|c|c|c|c|c|}
\hline \multirow[b]{2}{*}{ Item } & \multicolumn{4}{|c|}{ Treatment $^{1}$} & \multirow[b]{2}{*}{ SEM } & \multicolumn{3}{|c|}{$P$-value ${ }^{2}$} \\
\hline & Control & $\mathrm{FO}$ & $\mathrm{SFO}$ & LFO & & 1 & 2 & 3 \\
\hline \multicolumn{9}{|l|}{ Intake, kg/d } \\
\hline Silage DM & 10.9 & 10.1 & 7.93 & 8.43 & 0.67 & $<0.01$ & 0.01 & 0.36 \\
\hline Total DM & 18.2 & 17.4 & 14.9 & 13.9 & 1.18 & $<0.05$ & $<0.05$ & 0.33 \\
\hline $\mathrm{OM}$ & 16.6 & 15.9 & 13.7 & 12.7 & 1.08 & $<0.05$ & $<0.05$ & 0.32 \\
\hline NDF & 6.83 & 6.39 & 5.21 & 5.11 & 0.423 & $<0.01$ & 0.01 & 0.80 \\
\hline $\mathrm{pdNDF}^{3}$ & 5.61 & 5.25 & 4.26 & 4.21 & 0.345 & $<0.01$ & 0.01 & 0.86 \\
\hline $\mathrm{CP}$ & 2.85 & 2.70 & 2.26 & 2.05 & 0.189 & 0.01 & 0.01 & 0.28 \\
\hline \multicolumn{9}{|l|}{ Fatty acids, g/d } \\
\hline $14: 0$ & 1.41 & 15.3 & 15.4 & 15.1 & 0.11 & $<0.001$ & 0.95 & 0.03 \\
\hline $16: 0$ & 62.1 & 86.4 & 106 & 92.0 & 4.23 & $<0.001$ & 0.01 & 0.01 \\
\hline $16: 1$ cis- 9 & 1.80 & 16.6 & 16.3 & 16.3 & 0.14 & $<0.001$ & 0.07 & 0.77 \\
\hline $16: 1$ cis-11 & 0.18 & 0.54 & 0.52 & 0.48 & 0.017 & $<0.001$ & 0.07 & 0.14 \\
\hline $16: 1$ trans -3 & 3.96 & 3.70 & 2.93 & 3.07 & 0.225 & $<0.01$ & $<0.01$ & 0.40 \\
\hline $16: 2$ cis- 6, cis $-9^{4}$ & 0.00 & 0.39 & 0.39 & 0.39 & 0.003 & $<0.001$ & 1.00 & 1.00 \\
\hline $16: 2$ cis- 9, cis- $12(16: 2 \mathrm{n}-4)$ & 0.00 & 2.11 & 2.11 & 2.11 & 0.006 & $<0.001$ & 1.00 & 1.00 \\
\hline $16: 2$ cis -11, cis- $15^{5}$ & 0.00 & 2.12 & 2.12 & 2.12 & 0.004 & $<0.001$ & 1.00 & 1.00 \\
\hline $16: 3$ cis- 6, cis- 9, cis- $12(16: 3 \mathrm{n}-4)^{6}$ & 0.00 & 2.62 & 2.62 & 2.62 & 0.006 & $<0.001$ & 1.00 & 1.00 \\
\hline $16: 4$ cis-4, cis- 7, cis- 10, cis- $13(16: 4 n-3)$ & 0.00 & 0.23 & 0.23 & 0.23 & 0.005 & $<0.001$ & 1.00 & 1.00 \\
\hline $16: 4$ cis- 6, cis- 9, cis- 12, cis $-15(16: 4 n-1)^{7}$ & 0.00 & 3.93 & 3.93 & 3.93 & 0.006 & $<0.001$ & 1.00 & 1.00 \\
\hline $18: 0$ & 6.25 & 11.8 & 27.8 & 23.4 & 0.46 & $<0.001$ & $<0.001$ & $<0.001$ \\
\hline $18: 1$ cis-9 & 74.9 & 88.6 & 209 & 147 & 6.5 & $<0.001$ & $<0.001$ & $<0.001$ \\
\hline $18: 1$ cis- 11 & 10.6 & 15.8 & 17.2 & 15.6 & 0.96 & $<0.01$ & 0.56 & 0.24 \\
\hline $18: 2$ cis-9, cis-12 (18:2n-6) & 131 & 129 & 400 & 170 & 9.7 & $<0.001$ & $<0.001$ & $<0.001$ \\
\hline $18: 3$ cis-6, cis-9,cis-12 (18:3n-6) & 0.00 & 0.43 & 0.43 & 0.43 & 0.000 & $<0.001$ & 1.00 & 1.00 \\
\hline $18: 3$ cis- 9, cis- 11, cis-14 (18:3n-4) & 0.00 & 0.23 & 0.23 & 0.23 & 0.001 & $<0.001$ & 1.00 & 1.00 \\
\hline $18: 3$ cis- 9, cis- 12, cis- $15(18: 3 \mathrm{n}-3)$ & 132 & 127 & 104 & 379 & 7.4 & $<0.001$ & $<0.001$ & $<0.001$ \\
\hline $18: 4$ cis- 6, cis- 9, cis- 12, cis- $15(18: 4 \mathrm{n}-3)$ & 0.00 & 6.03 & 6.30 & 6.03 & 0.010 & $<0.001$ & $<0.001$ & $<0.001$ \\
\hline $18: 4$ cis- 9, cis- 11, cis- 14, cis- 17 & 0.00 & 0.49 & 0.49 & 0.49 & 0.002 & $<0.001$ & 1.00 & 1.00 \\
\hline 20:0 & 3.18 & 3.60 & 4.33 & 3.54 & 0.177 & $<0.01$ & $<0.05$ & $<0.01$ \\
\hline $20: 1$ cis -11 & 0.00 & 3.15 & 3.96 & 4.06 & 0.015 & $<0.001$ & $<0.001$ & $<0.01$ \\
\hline $20: 1$ cis -13 & 0.00 & 0.44 & 0.44 & 0.44 & 0.002 & $<0.001$ & 1.00 & 1.00 \\
\hline $20: 1$ cis -15 & 0.00 & 0.08 & 0.08 & 0.08 & 0.003 & $<0.001$ & 1.00 & 1.00 \\
\hline $20: 2$ cis- 11, cis- $14(20: 2 \mathrm{n}-6)$ & 0.00 & 0.34 & 0.34 & 0.57 & 0.002 & $<0.001$ & $<0.001$ & $<0.001$ \\
\hline $20: 2$ cis -8, cis -11 & 0.00 & 0.24 & 0.24 & 0.24 & 0.004 & $<0.001$ & 1.00 & 1.00 \\
\hline $20: 3$ cis- 8, cis- 11, cis- 14 & 0.00 & 0.67 & 0.67 & 0.79 & 0.011 & $<0.001$ & $<0.01$ & $<0.001$ \\
\hline $20: 3$ cis- 11, cis- 14, cis $-17(20: 3 \mathrm{n}-3)^{8}$ & 1.52 & 2.10 & 1.83 & 2.69 & 0.089 & $<0.001$ & $<0.05$ & $<0.001$ \\
\hline $20: 4$ cis- 5, cis- 8, cis- 11, cis- $14(20: 4 \mathrm{n}-6)^{9}$ & 0.00 & 1.84 & 1.84 & 1.84 & 0.005 & $<0.001$ & 1.00 & 1.00 \\
\hline $20: 4$ cis- 8, cis- 11, cis- 14, cis- $17(20: 4 n-3)$ & 0.00 & 1.76 & 1.76 & 1.76 & 0.006 & $<0.001$ & 1.00 & 1.00 \\
\hline $20: 5$ cis- 5, cis- 8, cis- 11, cis- 14, cis- 17 (20:5n-3) & 0.00 & 31.3 & 31.3 & 31.3 & 0.079 & $<0.001$ & 1.00 & 1.00 \\
\hline 21:0 & 1.33 & 1.28 & 1.10 & 1.07 & 0.080 & $<0.01$ & $<0.01$ & 0.54 \\
\hline $21: 5$ cis- 6, cis- 9, cis- 12, cis- 15, cis- 18 (21:5n-3) & 0.00 & 1.32 & 1.32 & 1.32 & 0.003 & $<0.001$ & 1.00 & 1.00 \\
\hline $22: 0$ & 3.80 & 3.79 & 6.42 & 3.66 & 0.228 & 0.001 & $<0.001$ & $<0.001$ \\
\hline $22: 1$ cis -11 & 0.00 & 2.14 & 2.14 & 2.20 & 0.006 & $<0.001$ & $<0.01$ & $<0.001$ \\
\hline $22: 2$ cis- 13, cis- $16(22: 3 \mathrm{n}-6)$ & 0.00 & 0.13 & 0.13 & 0.13 & 0.001 & $<0.001$ & 1.00 & 1.00 \\
\hline $22: 3$ cis- 13, cis- 16, cis- $19(22: 3 \mathrm{n}-3)^{10}$ & 0.52 & 1.32 & 1.35 & 1.33 & 0.047 & $<0.001$ & 0.58 & 0.77 \\
\hline $22: 4$ cis- 7, cis- 10, cis- 13, cis- $16(22: 4 \mathrm{n}-6)$ & 0.00 & 0.14 & 0.14 & 0.14 & 0.001 & $<0.001$ & 1.00 & 1.00 \\
\hline $22: 4$ cis- 10, cis- 13, cis- 16, cis- $19(22: 4 n-3)$ & 0.00 & 0.16 & 0.16 & 0.16 & 0.003 & $<0.001$ & 1.00 & 1.00 \\
\hline $22: 5$ cis- 4, cis- 7, cis- 10, cis -13, cis- 16 & 0.00 & 0.55 & 0.55 & 0.55 & 0.005 & $<0.001$ & 1.00 & 1.00 \\
\hline $22: 5$ cis- 7, cis-10,cis-13,cis-16,cis-19 (22:5n-3) & 0.00 & 3.60 & 3.60 & 3.60 & 0.009 & $<0.001$ & 1.00 & 1.00 \\
\hline $22: 6$ cis-4,cis-7,cis-10,cis-13,cis-16,cis-19 (22:6n-3) & 0.00 & 20.0 & 20.0 & 20.0 & 0.066 & $<0.001$ & 1.00 & 1.00 \\
\hline $23: 5$ cis- 10, cis- 13, cis- 16, cis- 19, cis- 20 & 0.00 & 0.03 & 0.03 & 0.03 & 0.001 & $<0.001$ & 1.00 & 1.00 \\
\hline $24: 0$ & 2.91 & 2.91 & 3.57 & 2.73 & 0.176 & 0.21 & 0.08 & $<0.001$ \\
\hline $24: 5$ cis- 9, cis- 12, cis- 15, cis- 18, cis- 21 & 0.00 & 0.30 & 0.30 & 0.30 & 0.002 & $<0.001$ & 1.00 & 1.00 \\
\hline $24: 6$ cis- 6, cis- 9, cis- 12, cis- 15, cis- 18, cis- 21 & 0.00 & 0.32 & 0.32 & 0.32 & 0.003 & $<0.001$ & 1.00 & 1.00 \\
\hline$\Sigma$ SFA & 95.1 & 146 & 183 & 160 & 5.97 & $<0.001$ & 0.001 & $<0.01$ \\
\hline$\Sigma$ MUFA & 94.3 & 138 & 260 & 197 & 7.73 & $<0.001$ & $<0.001$ & $<0.001$ \\
\hline$\Sigma$ PUFA & 266 & 341 & 592 & 635 & 16.2 & $<0.001$ & $<0.001$ & $<0.05$ \\
\hline$\Sigma$ Total fatty acids & 474 & 644 & 1052 & 1011 & 30.8 & $<0.001$ & $<0.001$ & 0.21 \\
\hline
\end{tabular}

${ }^{1}$ Refers to grass silage-based diet (forage:concentrate ratio 60:40, on a DM basis) supplemented with no additional oil (control), $200 \mathrm{~g}$ of fish oil (FO), $200 \mathrm{~g}$ of FO and $500 \mathrm{~g}$ of sunflower oil (SFO), or $200 \mathrm{~g}$ of FO and $500 \mathrm{~g}$ of linseed oil (LFO), respectively.

${ }^{2}$ Significance of single degree of freedom orthogonal contrasts comparing the control versus lipid supplemented diets (1), FO versus SFO and LFO (2), and SFO versus $\mathrm{LFO}(3)$.

${ }^{3}$ Potentially digestible NDF.

${ }^{4}$ Co-elutes with trans-9 17:1.

${ }^{5}$ Co-elutes with trans-10 17:1.

${ }^{6}$ Co-elutes with trans-9 18:1.

${ }^{7}$ Co-elutes with trans-9, cis-12 18:2.

${ }^{8}$ Co-elutes with cis-13 22:1.

${ }^{9}$ Co-elutes with cis-15 22:1.

${ }^{10}$ Co-elutes with cis-15 24:1 in FO supplemented treatments. Contains only cis-15 24:1 in a control treatment. 
Table 2. Rumen fermentation characteristics and rumen microbial populations of lactating cows fed a grass silage-based diet supplemented with fish oil or a mixture of fish oil with either sunflower oil or linseed oil

\begin{tabular}{|c|c|c|c|c|c|c|c|c|}
\hline \multirow[b]{2}{*}{ Item } & \multicolumn{4}{|c|}{ Treatment $^{1}$} & \multirow[b]{2}{*}{ SEM } & \multicolumn{3}{|c|}{$P$-value ${ }^{2}$} \\
\hline & Control & FO & SFO & LFO & & 1 & 2 & 3 \\
\hline Ammonia-N, mmol/L & 4.61 & 4.70 & 3.60 & 4.03 & 0.771 & 0.53 & 0.31 & 0.65 \\
\hline Total VFA, mmol/L & 106 & 104 & 95.5 & 96.3 & 3.98 & 0.15 & 0.12 & 0.89 \\
\hline \multicolumn{9}{|l|}{ Molar proportions, $\mathrm{mmol} / \mathrm{mol}$} \\
\hline Acetate & 653 & 649 & 619 & 613 & 7.4 & 0.01 & $<0.01$ & 0.55 \\
\hline Isobutyrate & 7.27 & 7.40 & 7.30 & 7.01 & 0.263 & 0.85 & 0.15 & 0.20 \\
\hline Valerate & 12.8 & 12.2 & 13.3 & 12.6 & 0.36 & 0.85 & 0.17 & 0.22 \\
\hline Isovalerate & 11.0 & 11.4 & 14.2 & 17.0 & 1.31 & 0.05 & $<0.05$ & 0.13 \\
\hline Caproate & 4.44 & 4.04 & 3.55 & 2.66 & 0.256 & 0.01 & 0.01 & $<0.05$ \\
\hline Molar acetate:propionate ratio, $\mathrm{mol} / \mathrm{mol}$ & 3.57 & 3.59 & 2.90 & 2.78 & 0.185 & 0.05 & 0.01 & 0.66 \\
\hline
\end{tabular}

${ }^{1}$ Refers to grass silage-based diet (forage:concentrate ratio 60:40, on a DM basis) supplemented with no additional oil (control), $200 \mathrm{~g}$ of fish oil (FO), $200 \mathrm{~g}$ of FO and $500 \mathrm{~g}$ of sunflower oil (SFO), or $200 \mathrm{~g}$ of FO and $500 \mathrm{~g}$ of linseed oil (LFO), respectively.

${ }^{2}$ Significance of single degree of freedom orthogonal contrasts comparing the control versus lipid supplemented diets (1), FO versus SFO and LFO diets (2), and SFO versus LFO (3).

roate. Compared with FO, plant oils plus FO lowered $(P<0.05)$ acetate and caproate, but increased $(P<$ $0.05)$ molar proportions of propionate and isovalerate, whereas LFO decreased $(P<0.05)$ caproate compared with SFO (Table 2).

\section{Nutrient Flow at the Omasum}

Oil supplements lowered $(P<0.05)$ the flow of DM, VFA, and $\mathrm{N}$ at the omasum (Table 3 ). Compared with FO alone, the addition of plant oils decreased $(P<$ $0.05)$ VFA and $\mathrm{N}$ at the omasum, but the effects of SFO and LFO did not differ. Inclusion of oil in the diet increased $(P<0.05)$ the flow of 16:0, total 16:1, 18:1, 18:2, trans FA (TFA), MUFA, and PUFA (Table 3) at the omasum. Compared with the control, oil supplements had no effect on the amount of 18:0 and SFA leaving the rumen. The same was true when FO was compared with SFO and LFO, but the flows of 18:0 and SFA differed $(P<0.05)$ between SFO and LFO (Table 3). Plant oils increased $(P<0.05)$ the amount of trans-18:1, total 18:2, TFA, MUFA, and PUFA at the omasum compared with FO alone, with the amounts of total 18:2, TFA, and PUFA being higher $(P<0.05)$ for LFO than SFO (Table 3).

Oil supplements decreased $(P<0.01) 18: 2 \mathrm{n}-6$ and $18: 3 n-3$ at the omasum, with the amount of $18: 3 n-3$ being lower $(P<0.01)$ when plant oils were fed compared with FO alone (Table 3). Relative to the control, oil supplements had no effect on cis-9,trans-11,cis-15 18:3 at the omasum, whereas the flow was higher $(P<0.05)$ on LFO than SFO. Inclusion of oils in the diet resulted in relatively minor increases $(P \leq 0.05)$ or no change in the flow of odd- and branched-chain FA (OBCFA) at the omasum, but increased $(P<0.05)$ 10-O-18:0 and 15-O-18:0 at the omasum compared with the control (Supplemental Table S4; https://doi.org/10.3168/jds .2017-13776). Plant oils plus FO increased $(P \leq 0.05)$ the flow of 10-O-18:0 and 15-O-18:0 compared with FO alone.

Compared with the control, oil supplements increased $(P<0.01)$ cis $(\Delta 8-12) 16: 1$, trans $(\Delta 5-12) 16: 1$, and trans,trans $(\Delta 9,14 ; 10,14 ; 11,15) 16: 2$ at the omasum (Table 4 and Supplemental Table S5; https://doi.org/10 $.3168 /$ jds.2017-13776). Flow of several cis $(\Delta 9-12)$ and trans $(\Delta 6,7,11,12) 16: 1$ isomers and trans-9,trans-14 16:2 were higher $(P<0.05)$ for $\mathrm{FO}$ alone compared with FO plus plant oils, whereas the reverse was true for trans-10 16:1 and trans-10,trans-14 16:2. Relative to SFO, LFO increased $(P<0.05)$ cis $(\Delta 9,10) 16: 1$, trans $(\Delta 8-10)$ 16:1, and trans-10,trans-14 16:2 and decreased $(P<0.05)$ cis-11 16:1 at the omasum (Table 4 and Supplemental Table S5).

Oil supplements altered the abundance of 18:1 and 18:2 isomers at the omasum, changes characterized by an increase $(P<0.05)$ in cis $(\Delta 11,13,15$, 16) $18: 1$, trans $(\Delta 6-8,10-13,15) 18: 1$, cis-9,trans- 12 $18: 2$, trans, cis $(\Delta 9,12 ; 10,15 ; 11,15 ; 12,15) 18: 2$, and trans,trans $(\Delta 9,14 ; 10,15 ; 11,14) 18: 2$ at the omasum (Table 4 and Supplemental Table S6; https://doi.org/ $10.3168 / j d s .2017-13776)$. Inclusion of plant oils with FO increased $(P<0.05)$ the amount of $\operatorname{cis}(\Delta 15,16)$ $18: 1$, trans $(\Delta 6-8,10) 18: 1$, and $18: 2$ intermediates other than cis-11,cis-14 18:2 compared with FO. Furthermore, the source of plant oil had a major influence on the amounts of specific 18:1 and 18:2 intermediates leaving the rumen. Compared with SFO, flows of cis $(\Delta 11,15)$ 18:1, trans-11 18:1, and 18:2 intermediates 
except cis-11,cis-14 18:2 were higher $(P<0.05)$ on the LFO treatment (Table 4 and Supplemental Table S6).

Oil supplements had no effect on cis-9,trans-11 CLA or total CLA at the omasum, but altered the relative abundance of minor isomers of CLA leaving the rumen (Table 4 and Supplemental Table S6; https://doi.org/ $10.3168 /$ jds.2017-13776), causing an increase $(P<0.05)$ in trans-7,cis-9 CLA, trans,trans $(\Delta 8,10 ; 9,11 ; 10,12)$ CLA and a decrease $(P<0.05)$ in trans-11, cis-13 CLA and trans-11,trans-13 CLA. Relative to FO, plant oils plus FO resulted in higher $(P<0.05)$ trans-10, cis-12 CLA and trans,trans $(\Delta 8,10 ; 10,12)$ CLA and lower $(P<0.05)$ trans-7, cis-9 CLA at the omasum (Table 4 and Supplemental Table S6). Compared with SFO, flows of trans-11,cis-13 CLA, and trans,trans $(\Delta 12,14$; 13,15) CLA were higher $(P<0.05)$ and the amount of trans-10, cis-12 CLA was lower $(P<0.05)$ on the LFO treatment (Table 4 and Supplemental Table S6).

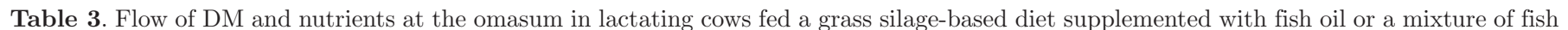
oil with either sunflower oil or linseed oil

\begin{tabular}{|c|c|c|c|c|c|c|c|c|}
\hline \multirow[b]{2}{*}{ Item } & \multicolumn{4}{|c|}{ Treatment $^{1}$} & \multirow[b]{2}{*}{ SEM } & \multicolumn{3}{|c|}{$P$-value ${ }^{2}$} \\
\hline & Control & $\mathrm{FO}$ & $\mathrm{SFO}$ & $\mathrm{LFO}$ & & 1 & 2 & 3 \\
\hline \multicolumn{9}{|l|}{ Flow, kg/d } \\
\hline DM & 11.5 & 10.7 & 8.76 & 8.49 & 0.96 & $<0.05$ & 0.06 & 0.81 \\
\hline $\mathrm{OM}^{3}$ & 8.70 & 8.12 & 6.70 & 6.38 & 0.775 & 0.06 & 0.08 & 0.72 \\
\hline $\mathrm{NDF}$ & 3.55 & 3.37 & 2.54 & 2.50 & 0.356 & 0.07 & 0.06 & 0.93 \\
\hline $\operatorname{pdNDF}^{4}$ & 2.55 & 2.42 & 1.75 & 1.75 & 0.290 & 0.10 & 0.08 & 1.00 \\
\hline VFA & 1.50 & 1.28 & 0.93 & 1.01 & 0.157 & 0.01 & $<0.05$ & 0.58 \\
\hline \multicolumn{9}{|l|}{ Flow, g/d } \\
\hline $\mathrm{N}$ & 444 & 418 & 339 & 297 & 37.9 & $<0.05$ & $<0.05$ & 0.36 \\
\hline NAN & 437 & 412 & 335 & 294 & 37.2 & $<0.05$ & $<0.05$ & 0.36 \\
\hline \multicolumn{9}{|l|}{ Fatty acids, g/d } \\
\hline $12: 0$ & 0.89 & 0.94 & 0.60 & 0.67 & 0.089 & 0.10 & 0.01 & 0.50 \\
\hline $14: 0$ & 2.22 & 6.17 & 4.98 & 5.60 & 0.519 & 0.001 & 0.20 & 0.42 \\
\hline $16: 0$ & 56.0 & 86.2 & 90.2 & 79.4 & 6.69 & 0.01 & 0.86 & 0.26 \\
\hline$\Sigma 16: 1$ cis & 7.74 & 15.2 & 5.50 & 5.59 & 0.909 & 0.14 & $<0.001$ & 0.91 \\
\hline$\Sigma 16: 1$ trans & 0.85 & 4.33 & 3.20 & 4.24 & 0.297 & $<0.001$ & 0.12 & $<0.05$ \\
\hline$\Sigma 16: 2$ cis,cis & 0.19 & 0.28 & 0.21 & 0.28 & 0.051 & 0.23 & 0.56 & 0.29 \\
\hline$\Sigma 16: 2$ trans, trans & 0.03 & 0.33 & 0.29 & 0.44 & 0.046 & $<0.001$ & 0.48 & 0.04 \\
\hline $18: 0$ & 226 & 130 & 258 & 93.7 & 33.8 & 0.17 & 0.31 & 0.01 \\
\hline$\Sigma 18: 1$ cis & 25.7 & 31.1 & 34.0 & 45.7 & 3.31 & 0.01 & $<0.05$ & $<0.05$ \\
\hline$\Sigma 18: 1$ trans & 46.3 & 135 & 255 & 289 & 25.2 & 0.001 & $<0.01$ & 0.34 \\
\hline $18: 2$ cis- 9, cis-12 $(18: 2 \mathrm{n}-6)^{5}$ & 17.8 & 11.9 & 9.94 & 6.76 & 1.779 & $<0.01$ & 0.09 & 0.17 \\
\hline$\Sigma 18: 2$ cis, cis & 18.3 & 12.2 & 10.4 & 7.02 & 1.81 & $<0.01$ & 0.12 & 0.25 \\
\hline$\Sigma 18: 2$ cis,trans/trans, cis & 4.37 & 11.2 & 14.7 & 64.1 & 3.21 & $<0.001$ & $<0.001$ & $<0.001$ \\
\hline$\Sigma 18: 2$ trans,trans & 1.46 & 4.34 & 4.26 & 21.3 & 1.33 & $<0.01$ & $<0.01$ & $<0.001$ \\
\hline$\Sigma \mathrm{CLA}$ & 4.67 & 4.76 & 4.85 & 3.89 & 0.783 & 0.79 & 0.56 & 0.24 \\
\hline $18: 3$ cis-9,cis-12,cis-15 (18:3n-3) ${ }^{6}$ & 7.42 & 5.86 & 2.67 & 4.37 & 0.517 & $<0.001$ & $<0.01$ & 0.01 \\
\hline $18: 3$ cis- 9, trans -11, cis- 15 & 1.15 & 1.20 & 0.79 & 3.60 & 0.754 & 0.44 & 0.32 & $<0.05$ \\
\hline $20: 0$ & 3.74 & 6.58 & 5.73 & 2.58 & 0.973 & 0.32 & 0.09 & 0.06 \\
\hline $24: 1$ cis-15 & 0.69 & 1.49 & 1.01 & 1.24 & 0.186 & $<0.05$ & 0.15 & 0.40 \\
\hline $26: 0$ & 10.2 & 13.9 & 5.40 & 4.07 & 1.202 & $<0.05$ & $<0.001$ & 0.23 \\
\hline $28: 0$ & 6.89 & 9.01 & 5.09 & 3.53 & 0.668 & 0.15 & $<0.001$ & 0.08 \\
\hline $30: 0$ & 4.70 & 5.50 & 4.57 & 3.06 & 0.592 & 0.66 & 0.06 & 0.12 \\
\hline Unidentified $^{7}$ & 3.65 & 13.0 & 9.60 & 11.3 & 1.06 & 0.001 & 0.09 & 0.31 \\
\hline$\Sigma \mathrm{TFA}^{8}$ & 60.8 & 183 & 305 & 408 & 29.8 & $<0.001$ & $<0.01$ & $<0.05$ \\
\hline$\Sigma \mathrm{SFA}$ & 333 & 291 & 431 & 231 & 40.6 & 0.75 & 0.46 & 0.01 \\
\hline$\Sigma$ MUFA & 83.9 & 204 & 312 & 361 & 30.2 & 0.001 & 0.01 & 0.5 \\
\hline$\Sigma$ PUFA & 48.7 & 78.4 & 76.6 & 145 & 6.97 & $<0.001$ & $<0.01$ & $<0.001$ \\
\hline$\Sigma$ Total fatty acids & 470 & 587 & 829 & 749 & 43.8 & $<0.01$ & 0.01 & 0.25 \\
\hline
\end{tabular}

${ }^{1}$ Refers to grass silage-based diet (forage:concentrate ratio 60:40, on a DM basis) supplemented with no additional oil (control), 200 g of fish oil (FO), $200 \mathrm{~g}$ of FO and $500 \mathrm{~g}$ of sunflower oil (SFO), or $200 \mathrm{~g}$ of FO and $500 \mathrm{~g}$ of linseed oil (LFO), respectively.

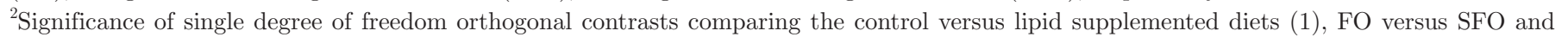
LFO diets (2), and SFO versus LFO (3).

${ }^{3}$ Measurements do not include volatile fatty acids.

${ }^{4}$ Potentially digestible NDF.

${ }^{5}$ Co-elutes with cis-9,cis-15 18:2 and cis-9,cis-14 18:2.

${ }^{6}$ Co-elutes with 20:1 cis-12.

${ }^{7}$ Sum of 31 minor fatty acids of indeterminate structure.

${ }^{8}$ Trans fatty acid. 
Table 4. Flow of selected 16- and 18-carbon fatty acids at the omasum in lactating cows fed a grass silage-based diet supplemented with fish oil or a mixture of fish oil with either sunflower oil or linseed oil

\begin{tabular}{|c|c|c|c|c|c|c|c|c|}
\hline \multirow[b]{2}{*}{ Flow, g/d } & \multicolumn{4}{|c|}{ Treatment $^{1}$} & \multirow[b]{2}{*}{ SEM } & \multicolumn{3}{|c|}{$P$-value ${ }^{2}$} \\
\hline & Control & $\mathrm{FO}$ & $\mathrm{SFO}$ & LFO & & 1 & 2 & 3 \\
\hline $16: 1$ cis $-9^{3}$ & 1.44 & 3.99 & 2.64 & 3.26 & 0.253 & 0.001 & $<0.01$ & $<0.05$ \\
\hline $16: 1$ cis-11 & 6.23 & 9.96 & 2.41 & 1.39 & 0.612 & 0.001 & $<0.001$ & $<0.05$ \\
\hline $16: 1$ trans -9 & 0.00 & 0.27 & 0.22 & 0.35 & 0.037 & 0.001 & 0.75 & 0.05 \\
\hline $16: 1$ trans -10 & 0.00 & 0.54 & 0.70 & 1.30 & 0.098 & $<0.001$ & 0.01 & $<0.01$ \\
\hline $16: 1$ trans $-11^{4}$ & 0.00 & 1.95 & 1.32 & 1.23 & 0.112 & $<0.001$ & 0.01 & 0.60 \\
\hline 18:1 cis-11 & 3.47 & 6.11 & 6.42 & 9.06 & 0.721 & $<0.01$ & 0.07 & $<0.05$ \\
\hline $18: 1$ cis- $15^{5}$ & 1.19 & 3.10 & 4.63 & 13.3 & 0.72 & $<0.001$ & $<0.001$ & $<0.001$ \\
\hline $18: 1$ trans $-6-7-8$ & 2.14 & 6.57 & 11.5 & 10.3 & 1.18 & $<0.01$ & $<0.05$ & 0.50 \\
\hline $18: 1$ trans -10 & 2.29 & 7.36 & 113 & 103 & 10.51 & 0.001 & $<0.001$ & 0.46 \\
\hline 18:1 trans -11 & 21.6 & 69.2 & 66.8 & 114 & 11.29 & $<0.01$ & 0.16 & $<0.05$ \\
\hline 18:1 trans $-13-14$ & 7.02 & 19.6 & 23.2 & 26.1 & 3.21 & $<0.01$ & 0.21 & 0.52 \\
\hline $18: 2$ trans -10, cis -15 & 0.00 & 0.81 & 5.20 & 35.8 & 1.86 & $<0.001$ & $<0.001$ & $<0.001$ \\
\hline CLA trans- 10, cis- 12 & 0.08 & 0.01 & 0.21 & 0.08 & 0.025 & 0.45 & $<0.01$ & 0.01 \\
\hline CLA trans-11,cis-13 & 0.64 & 0.46 & 0.13 & 0.39 & 0.095 & 0.01 & 0.07 & $<0.05$ \\
\hline CLA trans- 11, trans -13 & 0.32 & 0.09 & 0.06 & 0.17 & 0.038 & $<0.01$ & 0.53 & 0.07 \\
\hline CLA trans- 12, trans -14 & 0.13 & 0.07 & 0.06 & 0.15 & 0.021 & 0.19 & 0.14 & 0.01 \\
\hline
\end{tabular}

${ }^{1}$ Refers to grass silage-based diet (forage:concentrate ratio 60:40, on a DM basis) supplemented with no additional oil (control), $200 \mathrm{~g}$ of fish oil (FO), $200 \mathrm{~g}$ of FO and $500 \mathrm{~g}$ of sunflower oil (SFO), or $200 \mathrm{~g}$ of FO and $500 \mathrm{~g}$ of linseed oil (LFO), respectively.

${ }^{2}$ Significance of single degree of freedom orthogonal contrasts comparing the control versus lipid supplemented diets (1), FO versus SFO and LFO diets (2), and SFO versus LFO (3).

${ }^{3}$ Co-elutes with 17:0 anteiso.

${ }^{4}$ Co-elutes with cis-6 16:1.

${ }^{5}$ Co-elutes with 19:0, trans-9,trans-13 18:2, and trans-10,trans-14 18:2.

${ }^{6}$ Co-elutes with trans-11,trans-15 18:2.

${ }^{7}$ Co-elutes with trans-9,trans-12 18:2.

${ }^{8}$ Co-elutes with trans-10,trans-13 18:2, cis-9,trans-13 18:2, and cis-10,trans-14 18:2.

Oil supplements increased $(P<0.05)$ the flow of $\geq 20$-carbon FA at the omasum, including those contained in the FO supplement, several all-cis PUFA not supplied from the diet $(20: 2 \mathrm{n}-3,21: 3 \mathrm{n}-3,21: 4 \mathrm{n}-3$, and 22:3n-6), and numerous intermediates containing at least 1 trans double bond, including trans-13, cis-17 20:2, trans-7,cis-11,cis-14,cis-17 20:4, trans-12,cis16,cis-19 22:3, cis-7,trans-13,cis-16,cis-19 22:4, and trans-8,cis-13,cis-16,cis-19 22:4 (Table 5 and Supplemental Table S7; $\quad$ https://doi.org/10.3168/jds.2017 -13776). Inclusion of plant oils plus FO decreased $(P<$ 0.05) several all-cis PUFA, including 20:4n-6, 21:5n-3, $22: 4 \mathrm{n}-6$, and $22: 6 \mathrm{n}-3$, and increased $(P<0.05)$ multiple 20 - and 22-carbon intermediates at the omasum, including trans, cis and trans,trans $(\Delta 11,15 ; 13,17) 20: 2$, trans-11,cis-14,trans-17 20:3, and 22:4n-3 compared with FO. Furthermore, LFO resulted in higher $(P<$ $0.05)$ flows of specific 20- to 22-carbon intermediates, including trans-11,cis-15 20:2, trans,trans $(\Delta 10,16$;
11,15; 13,17) 20:2, cis-10,trans-14,cis-19 22:3, 22:4n-6, trans-8,cis-13,cis-16,cis-19 22:4, 22:4n-3, and 22:5n3 , but decreased $(P<0.05)$ the amounts of others, including trans-14,cis-17 20:2, cis-9,trans-14,trans-17 20:3, and 22:3n-3, compared with SFO (Table 5 and Supplemental Table S7).

On all diets, the amount of most PUFA at the omasum was lower than the respective intake, with the exception of 20:2n-6, 20:4n-3, 22:2n-6, and 22:4n-3 on the FO, SFO, and LFO treatments (Supplemental Table S8; https://doi.org/10.3168/jds.2017-13776). Compared with the control, oil supplements increased $(P<0.01)$ the extent of apparent cis-9 18:1, 18:2n-6, and 18:3n-3 biohydrogenation in the rumen (Table 6 ). Supplements of plant oils with FO resulted in more extensive $(P<0.05)$ metabolism of cis-9 18:1, 18:2n-6, 18:3n-3, and 22:6n-3 compared with FO, whereas the effect was close to significant with 20:5n-3 $(P=0.09)$. Biohydrogenation of 18:3n-3 was higher $(P<0.05)$ on 
Table 5. Flow of selected 20-, 21-, and 22-carbon fatty acids at the omasum in lactating cows fed a grass silage-based diet supplemented with fish oil or a mixture of fish oil with either sunflower oil or linseed oil

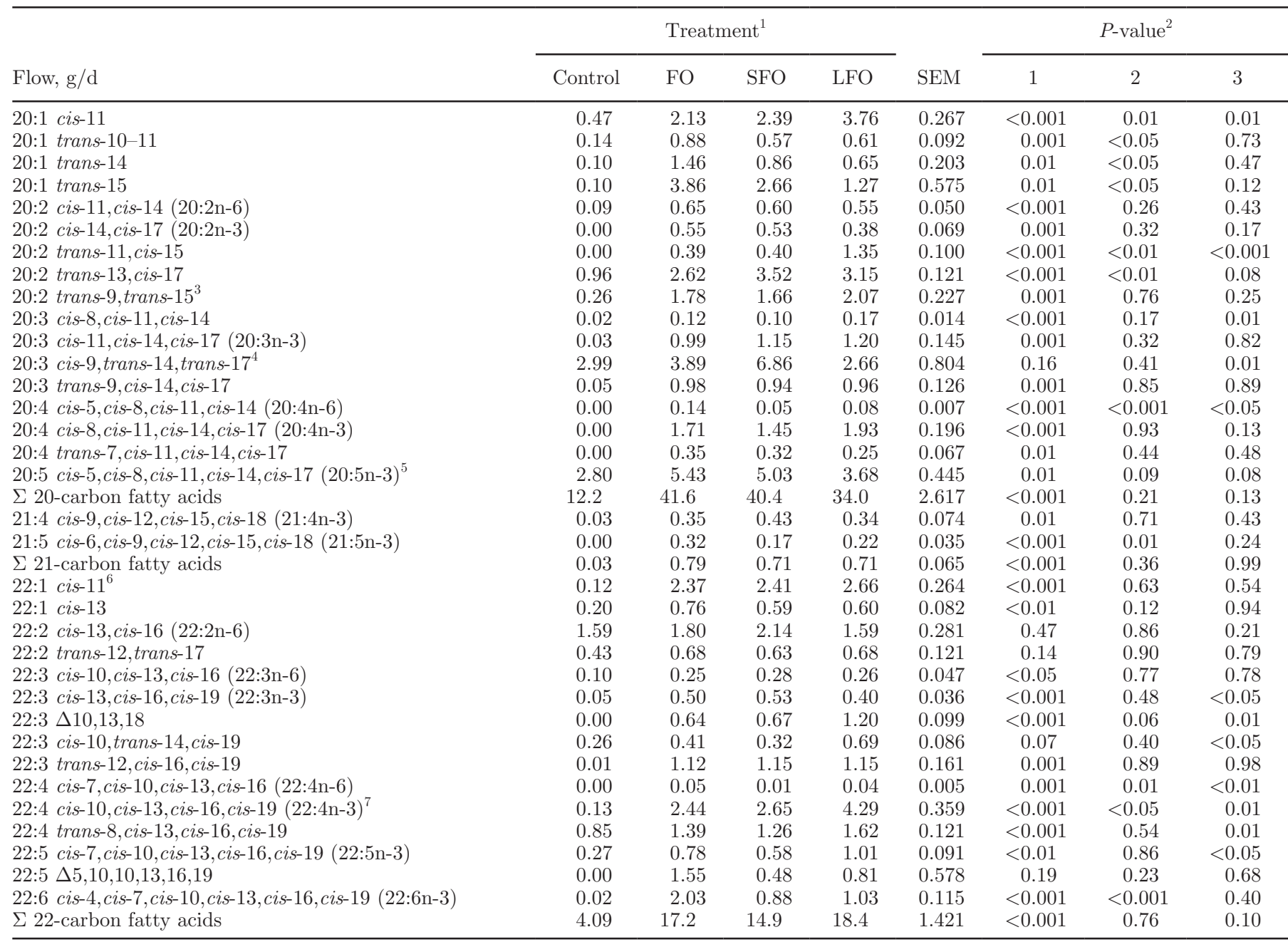

${ }^{1}$ Refers to grass silage-based diet (forage:concentrate ratio 60:40, on a DM basis) supplemented with no additional oil (control), $200 \mathrm{~g}$ of fish oil (FO), $200 \mathrm{~g}$ of FO and $500 \mathrm{~g}$ of sunflower oil (SFO), or $200 \mathrm{~g}$ of FO and $500 \mathrm{~g}$ of linseed oil (LFO), respectively.

${ }^{2}$ Significance of single degree of freedom orthogonal contrasts comparing the control versus lipid supplemented diets (1), FO versus SFO and LFO diets (2), and SFO versus LFO (3).

${ }^{3}$ Co-elutes with 21:0.

${ }^{4}$ Co-elutes with 22:0.

${ }^{5}$ Co-elutes with 24:0.

${ }^{6}$ Contains trans-11,cis-14,cis-17 20:3 as a minor component.

${ }^{7}$ Contains 8-O-16:0 as a minor component.

LFO than SFO, whereas the reverse was true for 22:5n3 (Table 6).

\section{Rumen Microbial Ecology}

Experimental treatments had no effect on ruminal protozoal numbers (Table 7). Of the species known to be capable of biohydrogenation, the group Butyrivibrio proteoclasticus was the most abundant, comprising up to $1.27 \%$ of total bacteria. The group encompassing Butyrivibrio fibrisolvens and known Pseudobutyrivibrio spp. were the next most numerous, whereas Butyrivibrio hungatei represented only a small proportion (0.04-0.05) of total Butyrivibrio + Pseudobutyrivibrio. Streptococcus bovis was present in $0.005 \%$ (average) of the bacterial community, but the numbers of Propionibacterium acnes were several orders of magnitude lower. Megasphaera elsdenii and the atypical B. fibrisolvens (which historically is the type strain) were below the limit of detection ( $10^{-7}$ of total bacteria) in all samples. Oil supplements had no effect on analyzed ruminal bacterial populations, whereas the abundance 
Table 6. Apparent ruminal biohydrogenation of dietary UFA in lactating cows fed a grass silage-based diet supplemented with fish oil or a mixture of fish oil with either sunflower oil or linseed oil

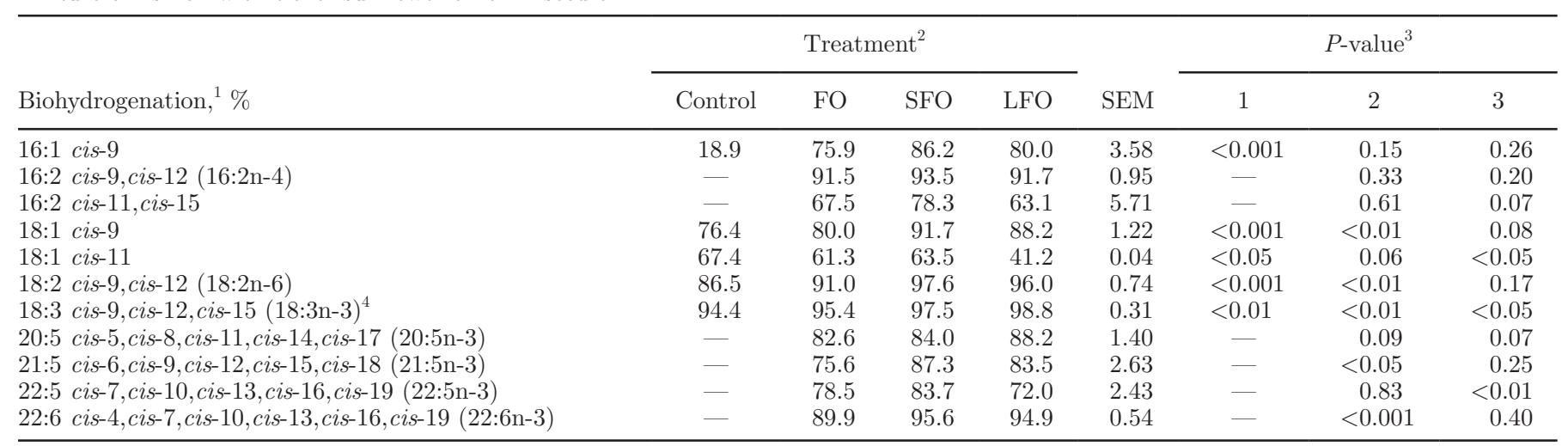

${ }^{1}$ Calculated as [(intake, g/d - flow at the omasum, g/d)/intake, g/d] $\times 100$.

${ }^{2}$ Refers to grass silage-based diet (forage:concentrate ratio 60:40, on a DM basis) supplemented with no additional oil (control), $200 \mathrm{~g}$ of fish oil (FO), $200 \mathrm{~g}$ of FO and $500 \mathrm{~g}$ of sunflower oil (SFO), or $200 \mathrm{~g}$ of FO and $500 \mathrm{~g}$ of linseed oil (LFO), respectively.

${ }^{3}$ Significance of single degree of freedom orthogonal contrasts comparing the control versus lipid supplemented diets (1), FO versus SFO and LFO diets (2), and SFO versus LFO (3).

${ }^{4}$ Co-elutes with cis-12 22:1.

of Oribacterium sp. was decreased $(P<0.05)$ on LFO compared with SFO (Table 7).

\section{DISCUSSION}

Dietary oil supplements decreased silage DMI even though cows were fed at a restricted level of intake. It is well established that FO and FO plus plant oils cause dose-dependent decreases in intake in lactating cows (Keady et al., 2000; Palmquist and Griinari, 2006; Shingfield et al., 2012). In the present study, the decrease in DMI to oil supplements were not ac- companied by adverse effects on ruminal or total-tract nutrient digestion, but seemed to increase whole-tract DM digestion; this may be explained by longer ruminal retention time caused by lower intake (Huhtanen and Kukkonen, 1995).

Inclusion of oils in the diet had no effect on rumen $\mathrm{pH}$, ammonia $\mathrm{N}$, or total VFA concentrations, but altered rumen fermentation, effects that were more pronounced for SFO and LFO compared with FO, with no evidence of differences due to the source of plant oil. In relatively low amounts, FO has rather small effects on rumen fermentation characteristics in lactating cows;

Table 7. Rumen microbial populations of lactating cows fed a grass silage-based diet supplemented with fish oil or a mixture of fish oil with either sunflower oil or linseed oil

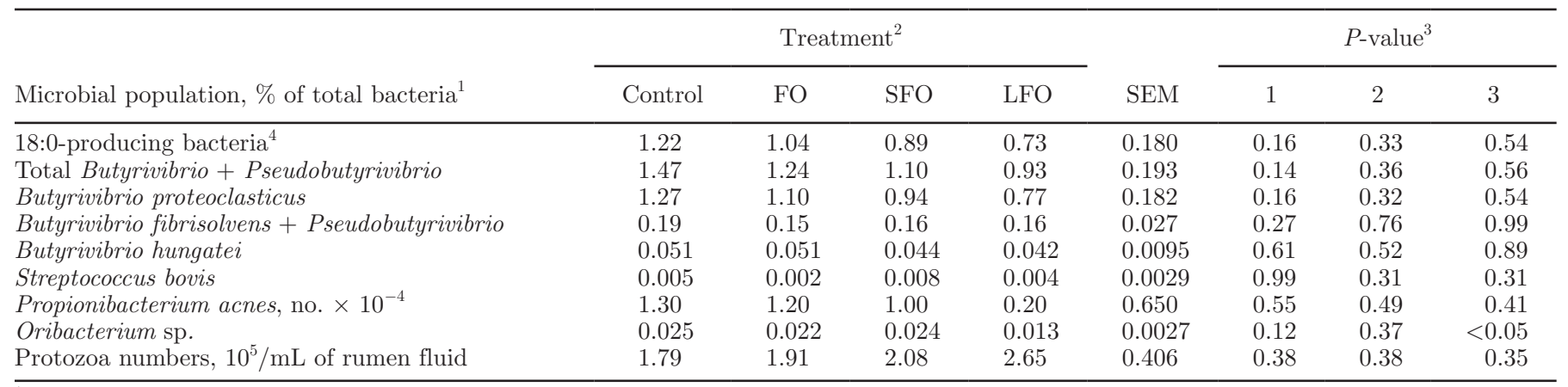

${ }^{1}$ Populations determined based on quantitative PCR using primers and probes designed to target different members of the Butyrivibrio/ Pseudobutyrivibrio group, S. bovis, P. acnes, and Oribacterium sp.

${ }^{2}$ Refers to grass silage-based diet (forage:concentrate ratio 60:40, on a DM basis) supplemented with no additional oil (control), $200 \mathrm{~g}$ of fish oil (FO), $200 \mathrm{~g}$ of FO and $500 \mathrm{~g}$ of sunflower oil (SFO), or $200 \mathrm{~g}$ of FO and $500 \mathrm{~g}$ of linseed oil (LFO), respectively.

${ }^{3}$ Significance of single degree of freedom orthogonal contrasts comparing the control versus lipid supplemented diets (1), FO versus SFO and LFO diets (2), and SFO versus LFO (3).

${ }^{4}$ Bacteria that are known to convert 18:1 trans-11 to 18:0, predominantly members of the B. proteoclasticus clade with some $B$. hungatei (Shingfield et al., 2012). 
however, higher levels of FO, or when fed with $\mathrm{SO}$, have been shown to induce larger changes in the relative proportions of gluconeogenic and ketogenic fermentation end-products (Shingfield et al., 2003; Palmquist and Griinari, 2006; Shingfield et al., 2012).

Alterations in ruminal biohydrogenation and the flow of FA at the omasum in response to oil supplements can be separated into the effects due to the metabolism of the long-chain UFA contained in FO and the associated effects on unsaturated 16- and 18-carbon FA, as well as the influence of the amount and source of dietary 18-carbon PUFA on these processes. Recoveries of 20:5n-3, 22:5n-3, and 22:6n-3 at the omasum on the FO, $\mathrm{SFO}$, and LFO treatments were marginal relative to the intake, in agreement with earlier studies reporting that long-chain n-3 PUFA are extensively biohydrogenated in the rumen of lactating cows (Shingfield et al., 2003; Loor et al., 2005; Shingfield et al., 2012).

During incubations with rumen contents, 18:2n-6 inhibited 20:5n-3 and 22:6n-3 biohydrogenation (Wasowska et al., 2006). Studies in growing cattle (Shingfield et al., 2011) and nonlactating sheep (Toral et al., 2010) fed diets containing plant oils and FO also suggested that the supply of 18-carbon PUFA may influence the extent of ruminal 20- and 22-carbon PUFA biohydrogenation. The present experiment provided the first direct evidence that metabolism of 22:6n-3 in the rumen of lactating cows is more extensive on diets containing higher amounts of 18-carbon PUFA, and the effect seemed to be similar with 20:5n-3. However, the biohydrogenation of 22:5n-3 was less extensive in LFO than SFO, but showed no difference between FO and diets containing plant oils. Such findings may help to explain, at least in part, the difference in the enrichment of 20:5n-3, 22:5n-3, and 22:6n-3 in muscle and milk from cattle fed dietary FO supplements under different study designs (Shingfield et al., 2013). More extensive metabolism of UFA in the rumen on the FO, LFO, and SFO treatments compared with the control was consistent with biohydrogenation representing a survival mechanism by removing the bacteriostatic effects of UFA below a certain threshold that would otherwise inhibit the growth of specific rumen bacteria.

Even though oil supplements increased 20-, 21-, and 22-carbon PUFA intake, the amounts of 20:0, 21:0, and 22:0 reaching the omasum were not substantially higher than the control, indicating that ruminal biohydrogenation of $\geq 20$-carbon PUFA to saturated end-products is incomplete. Some 20-, 21- and 22-carbon biohydrogenation intermediates detected in omasal digesta of cows fed FO but not on the control diet have been shown to be formed during metabolism of 20:5n-3, 22:5n-3, and 22:6n-3 in the rumen of lactating cows (Shingfield et al., 2003; Kairenius et al., 2011; Shingfield et al.,
2012). The differences in the ruminal biohydrogenation of 20:5n-3 and 22:5n-3 and the different flow of 20- to 22 -carbon intermediates at the omasum on LFO versus SFO suggests that the source of 18-carbon PUFA influences the kinetics of ruminal 20:5n-3, 22:5n-3, and 22:6n-3 metabolism.

The pathways of all-cis 20- to 22-carbon PUFA metabolism in the rumen are not well described. It has been suggested that the biohydrogenation of these FA may proceed via the reduction of cis double bonds closest to the carboxyl group, or via a specific mechanism that involves the sequential reduction of the cis-6 and cis-9 double bond (Kairenius et al., 2011). Flows of several all-cis 20- and 22-carbon FA, including 20:2n$6,20: 2 \mathrm{n}-3,20: 4 \mathrm{n}-3,22: 2 \mathrm{n}-6,22: 3 \mathrm{n}-6$, and $22: 4 \mathrm{n}-3$ at the omasum, exceeded intake, which would implicate these FA as intermediates of 20:5n-3, 22:5n-3 or 22:6n-3 metabolism. No conjugated 20- to 22-carbon FA were detected in omasal digesta, consistent with earlier investigations (Kairenius et al., 2011; Shingfield et al., 2012), suggesting that biohydrogenationn of long-chain PUFA does not involve isomerization and formation of intermediates containing a conjugated double bond system.

In the present study, oil supplements increased trans-16:1, trans-18:1, and trans-18:2 at the omasum relative to the control. The biohydrogenation of cis-9 18:1, 18:2n-6, and 18:3n-3 in oil-supplemented diets was also higher than biohydrogenation of these FA originating from ingredients of a control diet, being even greater when plant oils were fed with FO. Despite of a similar intake of 18-carbon PUFA and similar flow of trans-18:1, the flow of 18:0 at the omasum was lower and accumulation of trans-18:2 intermediates greater for LFO than SFO. Such findings indicate that the inhibitory effects of FO on the reduction of 18-carbon FA to $18: 0$ is influenced by the relative amounts of $18: 2 n-6$ and 18:3n-3 in the diet.

On the FO treatment, trans-11 18:1 and trans11,cis-15 18:2 were among the major biohydrogenation products. Inclusion of LO, but not SO, caused trans-11 18:1 to accumulate. In earlier studies, supplements of sunflower seeds or linseeds in combination with FO have been shown to elevate the proportion of trans-11 18:1 in ruminal (AbuGhazaleh et al., 2003) and duodenal digesta (Shingfield et al., 2011) of cattle. Some of these apparent discrepancies can be explained by differences in the influence of lipid supplements on the major biohydrogenation pathways in the rumen due to variation in 18-carbon FA intake within earlier investigations and the present study. In the present experiment, supplementing FO with sources of $18: 2 \mathrm{n}-6$ or $18: 3 \mathrm{n}-3$ caused trans-10 18:1 to accumulate, and, on the SFO treatment, trans-10 18:1 was the major biohydrogena- 
tion intermediate escaping the rumen. High amounts of FO (Loor et al., 2005; Shingfield et al., 2012), highstarch, low-fiber diets (Piperova et al., 2002; Zened et al., 2013), and high-concentrate diets containing plant oils (Loor et al., 2004; Ventto et al., 2017) have been shown to promote a shift in ruminal biohydrogenation pathways, promoting the formation of trans-10 18:1; however, the underlying causes are not known. It has been shown that trans-10 18:1 is formed from 18:2n-6 via reduction of $\Delta 10,12$ CLA isomers (Kepler et al., 1966; McKain et al., 2010) and may also be formed by isomerization of cis-9 18:1 (Mosley et al., 2002).

In vitro studies have suggested that a decrease in $\mathrm{pH}$ is associated with the shift from trans-11 18:1 to trans-10 18:1 in dual-flow continuous cultures (Fuentes et al., 2009). However, increases in trans-10 18:1 formation on the SFO and LFO treatment were not associated with a decrease in mean daily rumen $\mathrm{pH}$. Similarly, increases in trans-10 18:1 formation in cows fed high-starch, low-fiber diets (Piperova et al., 2002; Zened et al., 2013), high-concentrate diets containing plant oils (Loor et al., 2004; Ventto et al., 2017), or high amounts of FO (Shingfield et al., 2012) were not accompanied by decreases in rumen pH. Further investigations are required to provide an insight into the mechanisms involved and the associated changes in the rumen microbial community.

The major pathway of ruminal 18:3n-3 metabolism involves an initial isomerization to cis- 9 ,trans- 11 , cis- 15 18:3 and sequential reduction of double bonds to yield trans-11,cis-15 18:2 and trans-11 18:1 as intermediates (Harfoot and Hazlewood, 1988). Relative to SFO, the amounts of alternative novel trans-18:2 isomers, including trans-10,cis-15 18:2, trans-9,trans-14 18:2, trans-11,trans-15 18:2, trans-10,trans-15 18:2, and trans-9,trans-12 18:2, were increased on LFO, providing further evidence that multiple products are formed during the biohydrogenation of 18:3n-3 (Jouany et al., 2007; Alves and Bessa, 2014). Inclusion of LO with FO also altered the major pathways described for 18:3n3 , resulting in trans-10,cis-15 18:2 replacing trans11,cis-15 18:2 as the major 18:2 intermediate escaping the rumen. Recent studies have confirmed that trans10,cis-15 18:2 is formed from 18:3n-3 in vivo (Alves and Bessa, 2014) and in vitro (Honkanen et al., 2016).

Irrespective of diet, cis-9,trans-11 was the major isomer of CLA in omasal digesta, confirming previous reports in lactating cows fed diets based on grass silage (Shingfield et al., 2003, 2008a, 2012). Compared with the control, oil supplements increased several geometric isomers of $\Delta 9,11$ and $\Delta 10,12$ CLA at the omasum, consistent with earlier reports in ruminants fed diets containing $\mathrm{FO}$ alone or in a combination with plant oils rich in 18:2n-6 or 18:3n-3 (Toral et al., 2010; Shingfield et al., 2011). Inclusion of plant oils with FO increased ruminal trans-10,cis-12 CLA outflow in amounts greater for SFO than LFO. Typically, FO has minimal influence on ruminal trans-10, cis-12 CLA formation (Shingfield et al., 2003, 2010), whereas increases in dietary 18:2n-6 content often promote trans-10, cis-12 CLA synthesis (Sackmann et al., 2003; Shingfield et al., 2008a). Similarly, trans-11,cis-13 CLA and trans11,trans-13 CLA at the omasum were higher on LFO than SFO, consistent with studies in vitro indicating geometric $\Delta 11,13$ CLA isomers are formed during incomplete biohydrogenation of 18:3n-3 (Jouany et al., 2007; Honkanen et al., 2016).

Metabolism of 16-carbon UFA in the rumen is not well described. Formation of trans-16:1 and trans-16:2 isomers are thought to originate from incomplete biohydrogenation of 16:2n-4, 16:2n-7, 16:3n-4, 16:4n-1, and 16:4n-3 contained in FO (Shingfield et al., 2010, 2011, 2012). Irrespective of dietary lipid content, trans-11 16:1 was the major biohydrogenation intermediate on all oil-supplemented treatments. Including plant oils with FO altered the biohydrogenation of 16-carbon UFA, promoting the formation of trans-10-containing products (trans-10 16:1, trans-10,trans-14 16:2) in the rumen, suggesting that the mechanisms involved are common to both 16- and 18-carbon UFA.

Oil supplements had relatively minor effects on ruminal escape of OBCFA that originate from membrane lipid of rumen bacteria (Vlaeminck et al., 2006). Earlier reports in lactating cows have demonstrated that dietary supplements of FO (Shingfield et al., 2012), SO (Shingfield et al., 2008a), or LO (Loor et al., 2004) have variable effects on ruminal outflow of specific OBCFA that have been suggested to represent a proxy of the microbial community in the rumen (Vlaeminck et al., 2006).

Bacteria, rather than protozoa, are thought to be responsible for ruminal biohydrogenation, but relatively few strains capable of biohydrogenation have been identified (Harfoot and Hazlewood, 1988; Lourenço et al., 2010). The identification of specific microbial species able to catalyze 1 or more reactions remains challenging, as biohydrogenation intermediates and products may also be exchanged between populations. Among cultivated bacteria, all members of the Butyrivibrio group form cis-9,trans-11 CLA from 18:2n-6 much more rapidly than do other species, but only $B$. proteoclasticus is capable of reducing trans-11 18:1 to 18:0 (Wallace et al., 2006; Paillard et al., 2007). In the present experiment, the Butyrivibrio + Pseudobutyrivibrio group comprised 0.93 to $1.47 \%$ of total bacterial DNA, numbers higher than earlier estimates in cattle (Huws et al., 2010; Shingfield et al., 2012). The numbers of B. proteoclasticus did not differ due to treatment, con- 
sistent with earlier reports in lactating cows fed FO (Shingfield et al., 2012). Even though oil supplements altered the amounts of 18-carbon biohydrogenation intermediates and 18:0 at the omasum, no changes in other populations of rumen Butyrivibrio group were observed. The population sizes of $S$. bovis and P. acnes, ruminal species known to hydrate rather than hydrogenate cis-9 18:1 and 18:2n-6 (Hudson et al., 2000; Kim et al., 2008), were extremely small (approximately $\leq 0.001 \%$ of total bacteria) in omasal digesta and not affected by treatment.

It has often been assumed that the main FA in FO are responsible for the inhibitory effects on biohydrogenation, but based on the earlier investigations in vivo (Shingfield et al., 2012) or in vitro (Wasowska et al., 2006) it seems that FO inhibits ruminal biohydrogenation through a mechanism that is not solely explained by effects on B. fibrisolvens. Other bacteria, such as Ruminococcus albus, Eubacterium spp., and Treponema spp., have been described to hydrogenate FA (Yokoyama and Davis, 1971; Kemp et al., 1975). Recently we isolated strains of Oribacterium that converted 18:2n-6 to cis- $^{-9, t r a n s-11 ~ C L A ~ a n d ~ t r a n s-11 ~ 18: 1 ~(S . ~ M u e t z e l ~ a n d ~}$ R. J. Wallace, unpublished data). Including FO in the diet of growing cattle has been shown to induce changes in the number of other rumen bacterial strains, such as Anaerovirbrio lipolytica, Fibrobacter succinogenes, and Ruminococcus flavefaciens (Huws et al., 2010), suggesting a broader influence on ruminal lipid metabolism (Kim et al., 2008; Huws et al., 2010). Furthermore, a negative relationship between DNA concentrations from $B$. proteoclasticus strains and 18:0 at the duodenum was reported in earlier studies (Kim et al., 2008; Huws et al., 2010). No such relationship was observed in our experiment; it is possible, therefore, that unknown microbial species, not quantified here, are involved in FA biohydrogenation. Alternatively, direct inhibition of the biohydrogenation pathway, which does not lead to changes in the biohydrogenating community but alters the biohydrogenation products, could be the principal mode of action of the plant PUFA (Maia et al., 2007; Lourenço et al., 2010).

In summary, dietary supplements of FO alone or in combination with plant oils increase the amount of biohydrogenation intermediates escaping the rumen, but the alterations in the amount of intermediates at the omasum or ruminal biohydrogenation pathways were not accompanied by major changes in analyzed bacterial populations. The present experiment provided the first direct evidence that metabolism of 22:6n-3 in the rumen of lactating cows is more extensive on diets containing higher amounts of 18-carbon PUFA, with indication that the effect is similar for 20:5n-3, whereas the effect on 22:5n-3 biohydrogenation depended on the source of 18-carbon PUFA. The source of 18-carbon PUFA influenced the kinetics of ruminal metabolism of these very long-chain FA. Further studies using functional metagenomics approaches are needed to provide a greater insight into the microbiology of diet-induced changes in bacterial biohydrogenation within the rumen, knowledge that can be used to develop novel strategies to enhance the beneficial FA content of ruminant products such as meat and milk.

\section{ACKNOWLEDGMENTS}

The authors dedicate this article to the memory of late Kevin J. Shingfield with gratitude for his inspiration, guidance, and commitment to this work and above all for his warm and everlasting friendship. The authors appreciate the contribution of staff at the Animal Nutrition Section Metabolism Unit of MTT Agrifood Research Finland [Natural Resources Institute (LUKE) since 2015; Jokioinen, Finland] for the care of experimental animals and assistance during sample collection. Valued contributions of Minna Aalto (Luke, Jokioinen, Finland) and Nest McKain (University of Aberdeen, Aberdeen, UK) for help with lipid and microbial ecology analyses, respectively, are very much appreciated. The authors gratefully acknowledge members of the LUKE Feed Laboratory for assistance with sample analyses. Provision of ultra-refined herring and mackerel oil by Pronova Biocare AS (Aalesund, Norway) and sunflower oil by Raisioagro Ltd. (Raisio, Finland) are gratefully acknowledged. This work was supported by BioCLA, an European Union 5th Framework Program Project (QLK1-2002-023621, European Commission, Brussels, Belgium) Production of CLA Enriched Products by Natural Means. Collaboration between research partners was funded by LIPGENE (www.lipgene.tcd.ie), an EU Sixth Framework Programme Integrated Project (FOOD-CT-2003-505944, European Commission, Brussels, Belgium).

\section{REFERENCES}

AbuGhazaleh, A. A., D. J. Schingoethe, A. R. Hippen, and K. F. Kalscheur. 2003. Conjugated linoleic acid and vaccenic acid in rumen, plasma, and milk of cows fed fish oil and fats differing in saturation of 18 carbon fatty acids. J. Dairy Sci. 86:3648-3660.

Ahvenjärvi, S., A. Vanhatalo, P. Huhtanen, and T. Varvikko. 2000. Determination of reticulorumen and whole-stomach digestion in lactating cows by omasal canal or duodenal sampling. Br. J. Nutr. 83:67-77.

Alves, S. P., and R. J. B. Bessa. 2014. The trans-10,cis-15 18:2: a missing intermediate of trans-10 shifted rumen biohydrogenation pathway? Lipids 49:527-541.

Binnerts, W. T., A. T. van't Klooster, and A. M. Frens. 1968. Soluble chromium indicator measured by atomic absorption in digestion experiments. Vet. Rec. 82:470.

Chow, T. T., V. Fievez, A. P. Moloney, K. Raes, D. Demeyer, and S. De Smet. 2004. Effect of fish oil on in vitro rumen lipolysis, appar- 
ent biohydrogenation of linoleic and linolenic acid and accumulation of biohydrogenation intermediates. Anim. Feed Sci. Technol. $117: 1-12$

Eilander, A., R. K. Harika, and P. L. Zock. 2015. Intake and sources of dietary fatty acids in Europe: Are current population intakes of fats aligned with dietary recommendations? Eur. J. Lipid Sci. Technol. 117:1370-1377.

European Council. 1986. Council Directive of 24 November 1986 on the approximation of laws, regulations and administrative provisions of the Member States regarding the protection of animals used for experimental and other scientific purposes (86/609/EEC). Off. J. Eur. Comm. L358:1-28.

Fuentes, M. C., S. Calsamiglia, P. W. Cardozo, and B. Vlaeminck. 2009. Effect of $\mathrm{pH}$ and level of concentrate in the diet on the production of biohydrogenation intermediates in a dual-flow continuous culture. J. Dairy Sci. 92:4456-4466.

Griinari, J. M., B. A. Corl, S. H. Lacy, P. Y. Chouinard, K. V. Nurmela, and D. E. Bauman. 2000. Conjugated linoleic acid is synthesized endogenously in lactating dairy cows by $\Delta 9$-desaturase. J. Nutr. 130:2285-2291.

Halmemies-Beauchet-Filleau, A., P. Kairenius, S. Ahvenjärvi, L. K. Crosley, S. Muetzel, P. Huhtanen, A. Vanhatalo, V. Toivonen, R. J. Wallace, and K. J. Shingfield. 2013. Effect of forage conservation method on ruminal lipid metabolism and microbial ecology in lactating cows fed diets containing a 60:40 forage-to-concentrate ratio. J. Dairy Sci. 96:2428-2447.

Harfoot, C. G., and G. P. Hazlewood. 1988. Lipid metabolism in the rumen. Pages 285-322 in The Rumen Microbial Ecosystem. ed. Elsevier Science Publishing, New York, NY

Honkanen, A. M., H. Leskinen, V. Toivonen, N. McKain, R. J. Wallace, and K. J. Shingfield. 2016. Metabolism of $\alpha$-linolenic acid during incubations with strained bovine rumen contents: products and mechanisms. Br. J. Nutr. 115:2093-2105.

Hudson, J. A., Y. Cai, R. J. Corner, B. Morvan, and K. N. Joblin. 2000. Identification and enumeration of oleic acid and linoleic acid hydrating bacteria in the rumen of sheep and cows. J. Appl. Microbiol. 88:286-292.

Huhtanen, P., and U. Kukkonen. 1995. Comparison of methods, markers, sampling sites and models for estimating digesta passage kinetics in cattle fed at 2 levels of intake. Anim. Feed Sci. Technol. $52: 141-158$.

Huws, S. A., M. R. F. Lee, S. M. Muetzel, M. B. Scott, and R. J. Wallace. 2010. Forage type and fish oil causes shifts in rumen bacterial diversity. FEMS Microbiol. Ecol. 73:396-407.

Jouany, J. P., B. Lassalas, M. Doreau, and F. Glasser. 2007. Dynamic features of the rumen metabolism of linoleic acid, linolenic acid and linseed oil measured in vitro. Lipids 42:351-360.

Kairenius, P., V. Toivonen, and K. J. Shingfield. 2011. Identification and ruminal outflow of long-chain fatty acid biohydrogenation intermediates in cows fed diets containing fish oil. Lipids 46:587-606.

Keady, T. W. J., C. S. Mayne, and D. A. Fitzpatrick. 2000. Effects of supplementation of dairy cattle with fish oil on silage intake, milk yield and milk composition. J. Dairy Res. 67:137-153.

Kemp, P. R. W. White, and D. J. Lander. 1975. The hydrogenation of unsaturated fatty acids by five bacterial isolates from the sheep rumen, including a new species. J. Gen. Microbiol. 90:100-114.

Kepler, C. R., K. P. Hirons, J. J. McNeill, and S. B. Tove. 1966. Intermediates and products of the biohydrogenation of linoleic acid by Butyrivibrio fibrisolvens. J. Biol. Chem. 241:1350-1354.

Kim, E. J., S. A. Huws, M. R. F. Lee, J. D. Wood, S. M. Muetzel, R. J. Wallace, and N. D. Scollan. 2008. Fish oil increases the duodenal flow of long chain polyunsaturated fatty acids and trans-11 18:1 and decreases 18:0 in steers via changes in the rumen bacterial community. J. Nutr. 138:889-896.

Lock, A. L., and D. E. Bauman. 2004. Modifying milk fat composition of dairy cows to enhance fatty acids beneficial to human health. Lipids 39:1197-1206.

Loor, J. J., K. Ueda, A. Ferlay, Y. Chilliard, and M. Doreau. 2004. Biohydrogenation, duodenal flow, and intestinal digestibility of trans fatty acids and conjugated linoleic acids in response to di- etary forage:concentrate ratio and linseed oil in dairy cows. J Dairy Sci. 87:2472-2485

Loor, J. J., K. Ueda, A. Ferlay, Y. Chilliard, and M. Doreau. 2005. Intestinal flow and digestibility of trans fatty acids and conjugated linoleic acids (CLA) in dairy cows fed a high-concentrate diet supplemented with fish oil, linseed oil, or sunflower oil. Anim. Feed Sci. Technol. 119:203-225.

Lourenço, M., E. Ramos-Morales, and R. J. Wallace. 2010. The role of microbes in rumen lipolysis and biohydrogenation and their manipulation. Animal 4:1008-1023.

Maia, M. R. G., L. C. Chaudhary, L. Figueres, and R. J. Wallace. 2007. Metabolism of polyunsaturated fatty acids and their toxicity to the microflora of the rumen. Antonie van Leeuwenhoek 91:303-314.

McKain, N., K. J. Shingfield, and R. J. Wallace. 2010. Metabolism of conjugated linoleic acids and 18:1 fatty acids by ruminal bacteria: Products and mechanisms. Microbiology (Reading, Engl.) 156:579-588.

Mosley, E. E., G. L. Powell, M. B. Riley, and T. C. Jenkins. 2002. Microbial biohydrogenation of oleic acid to trans isomers in vitro. J. Lipid Res. 43:290-296.

Paillard, D., N. McKain, M. T. Rincon, K. J. Shingfield, D. I. Givens, and R. J. Wallace. 2007. Quantification of ruminal Clostridium proteoclasticum by real-time PCR using a molecular beacon approach. J. Appl. Microbiol. 103:1251-1261.

Palmquist, D. L., and J. M. Griinari. 2006. Milk fatty acid composition in response to reciprocal combinations of sunflower and fish oils in the diet. Anim. Feed Sci. Technol. 131:358-369.

Palmquist, D. L., A. L. Lock, K. J. Shingfield, and D. E. Bauman. 2005. Biosynthesis of conjugated linoleic acid in ruminants and humans. Pages 179-217 in Advances in Food and Nutrition Research. Taylor S. L., ed. Elsevier Academic Press, San Diego, CA.

Piperova, L. S., J. Sampugna, B. B. Teter, K. F. Kalscheur, M. P. Yurawecz, Y. Ku, K. M. Morehouse, and R. A. Erdman. 2002 Duodenal and milk trans octadecenoic acid and conjugated linoleic acid (CLA) isomers indicate that postabsorptive synthesis is the predominant source of cis-9-containing CLA in lactating dairy cows. J. Nutr. 132:1235-1241.

Sackmann, J. R., S. K. Duckett, M. H. Gillis, C. E. Realini, A. H. Parks, and R. B. Eggelston. 2003. Effects of forage and sunflower oil levels on ruminal biohydrogenation of fatty acids and conjugated linoleic acid formation in beef steers fed finishing diets. J. Anim. Sci. 81:3174-3181.

Shingfield, K. J., S. Ahvenjärvi, V. Toivonen, A. Ärölä, K. V. V. Nurmela, P. Huhtanen, and J. M. Griinari. 2003. Effect of dietary fish oil on biohydrogenation of fatty acids and milk fatty acid content in cows. Anim. Sci. 77:165-179.

Shingfield, K. J., S. Ahvenjärvi, V. Toivonen, A. Vanhatalo, P. Huhtanen, and J. M. Griinari. 2008a. Effect of incremental levels of sunflower-seed oil in the diet on ruminal lipid metabolism in lactating cows. Br. J. Nutr. 99:971-983

Shingfield, K. J., A. Ärölä, S. Ahvenjärvi, A. Vanhatalo, V. Toivonen, J. M. Griinari, and P. Huhtanen. 2008b. Ruminal infusions of cobalt-EDTA reduce mammary $\Delta$ 9-desaturase index and alter milk fatty acid composition in lactating cows. J. Nutr. 138:710-717.

Shingfield, K. J., M. Bonnet, and N. D. Scollan. 2013. Recent developments in altering the fatty acid composition of ruminant-derived foods. Animal 7:132-162.

Shingfield, K. J., S. Jaakkola, and P. Huhtanen. 2002. Effect of forage conservation method, concentrate level and propylene glycol on diet digestibility, rumen fermentation, blood metabolite concentrations and nutrient utilisation of dairy cows. Anim. Feed Sci. Technol. 97:1-21.

Shingfield, K. J., P. Kairenius, A. Ärölä, D. Paillard, S. Muetzel, S. Ahvenjärvi, A. Vanhatalo, P. Huhtanen, V. Toivonen, J. M. Griinari, and R. J. Wallace. 2012. Dietary fish oil supplements modify ruminal biohydrogenation, alter the flow of fatty acids at the omasum, and induce changes in the ruminal Butyrivibrio population in lactating cows. J. Nutr. 142:1437-1448. 
Shingfield, K. J., M. R. F. Lee, D. J. Humphries, N. D. Scollan, V. Toivonen, D. E. Beever, and C. K. Reynolds. 2011. Effect of linseed oil and fish oil alone or as an equal mixture on ruminal fatty acid metabolism in growing steers fed maize silage-based diets. J. Anim. Sci. 89:3728-3741.

Shingfield, K. J., M. R. F. Lee, D. J. Humphries, N. D. Scollan, V. Toivonen, and C. K. Reynolds. 2010. Effect of incremental amounts of fish oil in the diet on ruminal lipid metabolism in growing steers. Br. J. Nutr. 104:56-66.

Toral, P. G., A. Belenguer, K. J. Shingfield, G. Hervás, V. Toivonen, and P. Frutos. 2012. Fatty acid composition and bacterial community changes in the rumen fluid of lactating sheep fed sunflower oil plus incremental levels of marine algae. J. Dairy Sci. 95:794-806.

Toral, P. G., K. J. Shingfield, G. Hervás, V. Toivonen, and P. Frutos. 2010. Effect of fish oil and sunflower oil on rumen fermentation characteristics and fatty acid composition of digesta in ewes fed a high concentrate diet. J. Dairy Sci. 93:4804-4817.

Ventto, L., H. Leskinen, P. Kairenius, T. Stefański, A. R. Bayat, J. Vilkki, and K. J. Shingfield. 2017. Diet-induced milk fat depression is associated with alterations in ruminal biohydrogenation pathways and formation of novel fatty acid intermediates in lactating cows. Br. J. Nutr. 117:364-376.

Vlaeminck, B., V. Fievez, A. R. J. Cabrita, A. J. M. Fonseca, and R. J. Dewhurst. 2006. Factors affecting odd- and branched-chain fatty acids in milk: A review. Anim. Feed Sci. Technol. 131:389-417.
Wallace, R., L. C. Chaudhary, N. McKain, N. R. McEwan, A. J. Richardson, P. E. Vercoe, N. D. Walker, and D. Paillard. 2006. Clostridium proteoclasticum: A ruminal bacterium that forms stearic acid from linoleic acid. FEMS Microbiol. Lett. 265:195-201.

Wasowska, I., M. R. G. Maia, K. M. Niedźwiedzka, M. Czauderna, J. Ribeiro, E. Devillard, K. J. Shingfield, and R. J. Wallace. 2006. Influence of fish oil on ruminal biohydrogenation of C18 unsaturated fatty acids. Br. J. Nutr. 95:1199-1211.

Whitlock, L. A., D. I. Schingoethe, A. R. Hippen, K. F. Kalscheur, R. J. Baer, N. Ramaswamy, and K. M. Kasperson. 2002. Fish oil and extruded soybeans fed in combination increase conjugated linoleic acids in milk of dairy cows more than when fed separately. J. Dairy Sci. 85:234-243.

Yokoyama, M. T., and C. L. Davis. 1971. Hydrogenation of unsaturated fatty acids by Treponema (Borrelia) Strain B(2)5, a rumen spirochete. J. Bacteriol. 107:519-527.

Zened, A., F. Enjalbert, M. C. Nicot, and A. Troegeler-Meynadier. 2013. Starch plus sunflower oil addition to the diet of dry dairy cows results in a trans-11 to trans-10 shift of biohydrogenation. J. Dairy Sci. 96:451-459. 